INEEL/CON-98-00539

PREPRINT

\title{
Microbial Ecology Assessment of Mixed Copper Oxide/Sulfide Dump Leach Operation
}

\author{
D. F. Bruhn \\ D. N. Thompson \\ K. S. Noah
}

June 20, 1999 - June 23, 1999

\section{Biohydrometallurgy and Environment Toward the Mining of the $21^{\text {st }}$ Century}

This is a preprint of a paper intended for publication in a journal or proceedings. Since changes may be made before publication, this preprint should not be cited or reproduced without permission of the author.

This document was prepared as a account of work sponsored by an agency of the United States Government. Neither the United States Government nor any agency thereof, or any of their employees, makes any warranty, expressed or implied, or assumes any legal liability or responsibility for any third party's use, or the results of such use, of any information, apparatus, product or process disclosed in this report, or represents that its use by such third party would not infringe privately owned rights. The views expressed in this paper are not necessarily those of the U.S. Government or the 


\title{
Microbial Ecology Assessment of a Mixed Copper Oxide/Sulfide Dump Leach Operation
}

\author{
Debby F. Bruhn, David N. Thompson, and Karl S. Noah
}

Biotechnologies Department

Lockheed Martin Idaho Technologies Company

Idaho National Engineering and Environmental Laboratory

Idaho Falls, ID 83415-2203

Microbial consortia composed of complex mixtures of autotrophic and heterotrophic bacteria are responsible for the dissolution of metals from sulfide minerals. Thus, an efficient copper bioleaching operation depends on the microbial ecology of the system. A microbial ecology study of a mixed oxide/sulfide copper leaching operation was conducted using an "overlay" plating technique to differentiate and identify various bacterial consortium members of the genera Thiobacillus, "Leptospirillum", "Ferromicrobium", and Acidiphilium. Two temperatures $\left(30^{\circ} \mathrm{C}\right.$ and $\left.45^{\circ} \mathrm{C}\right)$ were used to select for mesophilic and moderately thermophilic bacteria. Cell numbers varied from $0-10^{6}$ cells/g dry ore, depending on the sample location and depth. After acid curing for oxide leaching, no viable bacteria were recovered, although inoculation of cells from raffinate re-established a microbial population after three months. Due to low the $\mathrm{pH}$ of the operation, very few non-iron-oxidizing acidophilic heterotrophs were recovered. Moderate thermophiles were isolated from the ore samples. Pregnant liquor solutions (PLS) and raffinate both contained a diversity of bacteria. In addition, an intermittently applied waste stream that contained high levels of arsenic and fluoride was tested for toxicity. Twenty vol\% waste stream in PLS killed $100 \%$ of the cells in 48 hours, indicating substantial toxicity and/or growth inhibition. The data indicate that bacteria populations can recover after acid curing, and that application of the waste stream to the dump should be avoided. Monitoring the microbial ecology of the leaching operation provided significant information that improved copper recovery.

\section{INTRODUCTION}

Complex microbial consortia of autotrophic and heterotrophic bacteria are known to be responsible for the dissolution of metals from sulfide minerals (1). The number and composition of the bacteria responsible for this oxidation vary within the heap and with time. Dumps present diverse and changing conditions affecting bacterial activity and survival, including temperature, $\mathrm{pH}, \mathrm{Eh}$ and solute concentration (2). Therefore, in order to optimize a copper bioleaching operation and determine whether the process is perturbed, it is important to assess the microbial ecology of the system. Several techniques have been used to evaluate the microbial diversity in the leaching environment. Some of these include Most Probable 
Number (MPN), 16S rRNA gene analysis, spacers between the 16S and 23S rRNA genes, immunofluorescence, fatty acid methyl esters, and plating (1,3-6). Most of these techniques suffer from limitations caused by the extremely acidic environment and either do not give complete species profiles or accurate counts of each species.

In this study, the microbial ecology of an oxide/sulfide copper leaching operation was assessed using an "overlay" selective plating technique in which an acidophilic heterotrophic bacterium is incorporated into the underlayer of a two-layer gel (7). This medium, which includes tetrathionate, ferrous iron, and tryptone soya broth, has been used successfully to culture all known iron-oxidizing mesophilic, and moderately thermophilic bacteria. The medium also allows differentiation and preliminary identification of isolates by colony morphology. Bacteria were recovered from surface ore, ore samples from depth, pregnant liquor solution, raffinate, "On" solution (solution applied to the surface of the dumps) and makeup water. Samples were screened for commonly occurring iron- and sulfur-oxidizing mesophilic and thermophilic organisms as described above. Several minimum inhibitory concentration studies were also done to assess the potential toxicity of solutions added in the leaching process to the microorganisms.

\section{MATERIAL AND METHODS}

Ore and liquid samples were collected from a large oxide/sulfide copper mine in the Southwestern U.S. The ore was composed of copper oxides, chalcocite, chrysocolla and trace amounts of chalcopyrite. At least 4 dumps, designated A-D, were included in the leaching system, each with several leach pads designated, for example, A(1) - A(n) for Dump A; see Figure 1. The dumps were acid-cured for 3-5 days with 200g/L sulfuric acid, rested for 3 days and then rinsed with raffinate for $\sim 120$ days. PLS from Dump D was used as "On" solution for Dumps C(1) and C(2). A waste stream mixed with raffinate was used as "On" solution for Dump A. "On" solution for Dump B consisted of raffinate, raffinate intermittently mixed with variable amounts of a waste stream, or with PLS from Dump A.

Several water chemistry measurements, including $\mathrm{pH}$, Eh, total iron, ferrous iron, total copper, nitrates and phosphates were taken using standard techniques. Surface ore samples were taken from a total of six pads on two dumps, at various locations within the pads, and at various stages of the acid-curing process. These included samples from Dump C(2) (100 days after curing), Dump C(1) (recently cured), and Dumps B(1-3) (time since curing unknown). Three months later, samples were taken from Dump B(4) (immediately after curing), and Dump C(1). In addition, a tractor with a backhoe was used to dig two holes on Dump C(1) and two samples were taken at depth from each hole. Ore samples were taken with a shovel that was sterilized with a $1 \%$ bleach solution.

Ore samples were wet sieved to 6-10 mesh. Bacteria were washed from five grams of sieved ore in sterile $100 \mathrm{~mL}$ serum vials containing $50 \mathrm{~mL}$ of a pH 2.5 minimal salts solution containing $0.25 \mathrm{~g} / \mathrm{L}$ tryptone soya broth, $1.25 \mathrm{~g} / \mathrm{L}\left(\mathrm{NH}_{4}\right)_{2} \mathrm{SO}_{4}$, and $0.5 \mathrm{~g} / \mathrm{L} \mathrm{MgSO} \mathrm{MgH}_{2} \mathrm{O}$. The sample was placed on a wrist shaker for one hour at top speed and plated within one minute of removal from the shaker to avoid bacterial reattachment to the ore. Dilutions were performed in a minimal salts medium, and on-site water samples were plated within four to six hours. Bacteria were plated on an overlay medium (7) at $30^{\circ} \mathrm{C}$ to grow iron- and sulfur-oxidizing bacteria such as T. ferrooxidans, T. thiooxidans, "L. ferrooxidans" and " $F$. acidophilus". 


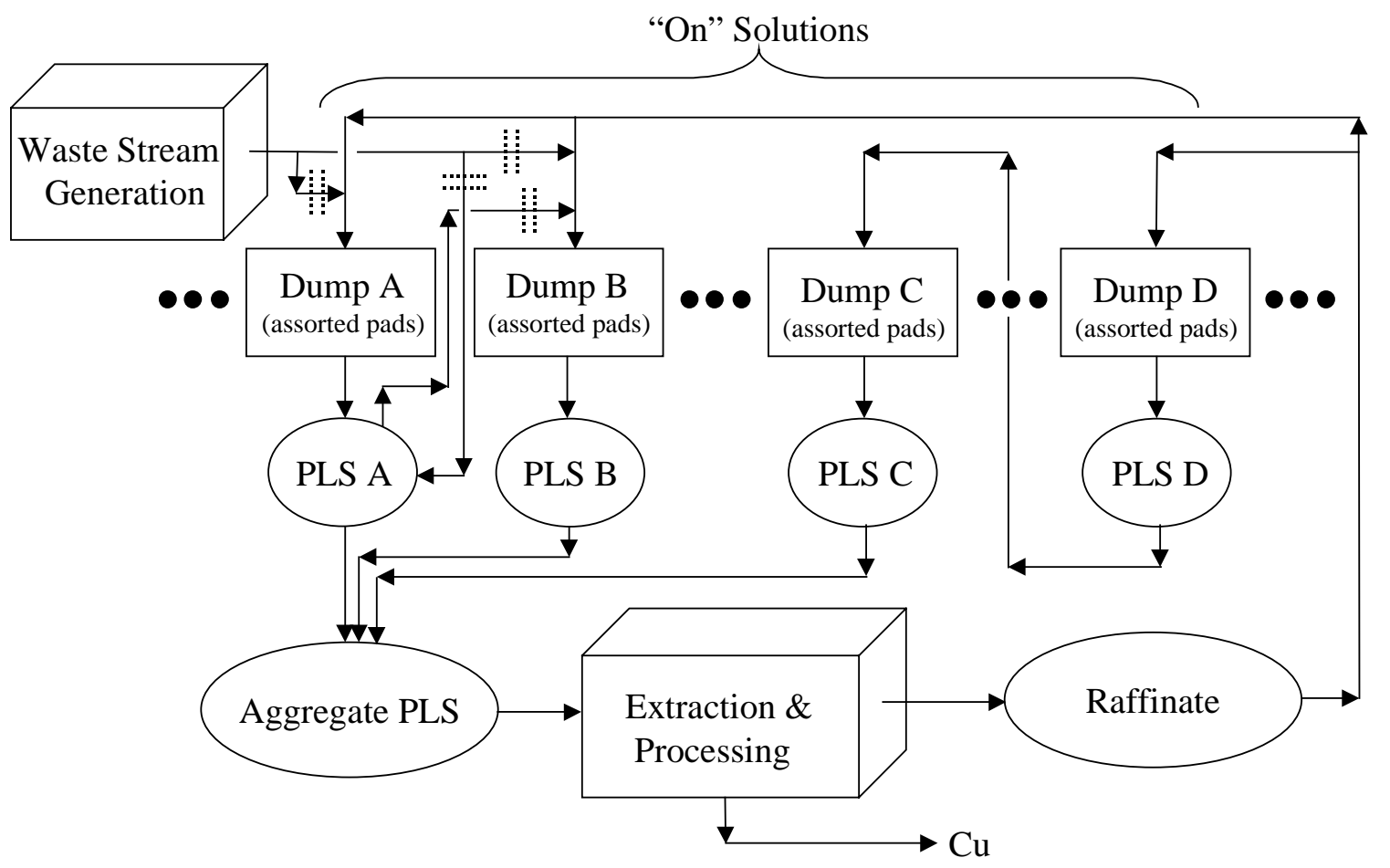

Figure 1: Flowchart showing the basic leaching operation and the interrelationships between the various leach solutions and ore samples. Squares represent dumps, ovals represent ponds, and cubes represent processing steps. The dashed pairs of lines near the outlet of the Waste Stream Generation indicate variable, intermittent flows.

Incubation of overlay plates at $45^{\circ} \mathrm{C}$ allowed screening for moderately thermophilic organisms including iron-oxidizing bacteria such as Sulfobacillus and/or Acidimicrobium, sulfur-oxidizing species such as T. caldus, and acidophilic heterotrophic bacteria such as Alicyclobacillus. Cycloheximide was incorporated into all media at $50 \mu \mathrm{g} / \mathrm{mL}$ to prevent fungal growth; cycloheximide was shown to be nontoxic to iron-oxidizing bacteria at this concentration (data not shown). Bacterial colonies were counted on all plates after 14 to 21 days.

A minimal inhibitory concentration (MIC) study was done on the waste stream that was applied to Dump B, which contained 250-1000 ppm arsenic and 400-500 ppm fluoride. The waste stream MIC study was done using PLS, which has higher cell numbers than the raffinate, at 1:30, 1:20, 1:10, and 1:5 (3.3, 5.0, 10, and 20 vol\% waste stream in PLS, respectively). Samples were taken at 0, 4, 24, and 48 hours into the run, and plated on overlay plates at $30^{\circ} \mathrm{C}$.

\section{RESULTS}

Water $\mathrm{pH}$ ranged from 1.2-1.8 for all liquid samples except for the makeup water which was pH 2.5 (Table 1). Eh values ranged from +400 to $+600 \mathrm{mV}$. Total iron, which was predominantly ferrous iron, was about $2000 \mathrm{ppm}$ in the pregnant liquor solution (PLS) and raffinate and slightly lower, at about 1200 ppm, in the "On" solutions. Nitrates and phosphates were present in all samples. 
Table 1: Water chemistry results for various samples.

\begin{tabular}{|c|c|c|c|c|c|c|c|}
\hline Sample & $\mathrm{pH}$ & $\begin{array}{c}\mathrm{Eh} \\
(\mathrm{mV})\end{array}$ & $\begin{array}{c}\text { Total } \\
\text { Fe } \\
(\mathrm{ppm})\end{array}$ & $\begin{array}{l}\mathrm{Fe}^{2+} \\
(\mathrm{ppm})\end{array}$ & $\begin{array}{c}\text { Total } \\
\mathrm{Cu} \\
(\mathrm{ppm})\end{array}$ & $\begin{array}{c}\text { Nitrate } \\
\mathrm{N} \\
(\mathrm{ppm})\end{array}$ & $\begin{array}{c}\text { Phosphate } \\
\text { P } \\
\text { (ppm) }\end{array}$ \\
\hline Aggregate PLS Pond & 1.8 & +413 & 1800 & 1900 & 2400 & 120 & 1.6 \\
\hline $\begin{array}{l}\text { Dump C “On" } \\
\text { Solution }\end{array}$ & 1.5 & +438 & 1300 & 1500 & 470 & 70 & 0.77 \\
\hline PLS Pond A & 1.2 & +398 & & 1300 & & 4.0 & 0.23 \\
\hline PLS Pond B & 1.8 & +410 & 1900 & 2400 & 2000 & 50 & 17 \\
\hline PLS Pond C & 1.8 & +418 & 1900 & 1600 & 2800 & 110 & 120 \\
\hline $\begin{array}{l}\text { Dump B “On" } \\
\text { Solution }\end{array}$ & 1.4 & +406 & 1200 & 1500 & 1600 & 4.0 & 0.43 \\
\hline Raffinate Pond & 1.7 & +418 & 1800 & 1800 & 170 & 25 & 100 \\
\hline Makeup Water & 2.5 & +536 & 17 & 56 & 100 & 9.0 & 0.00 \\
\hline
\end{tabular}

Three surface ore samples were taken from Dump C(2), which was acid-cured about 100 days earlier. Mesophilic iron- and sulfur-oxidizing bacterial cell counts ranged from $5.7 \times 10^{5}$ to $1.1 \times 10^{6}$ bacteria/g dry ore. There was some species diversity in these samples although no "L. ferrooxidans" were detected (Table 2). Acidiphilium-like heterotrophs were detected in only one sample.

Dump C(1) was sampled from one hole at $0,0.8$ and $1.7 \mathrm{~m}$ depths, and from another at $0,0.9$ and $2.6 \mathrm{~m}$. Mesophilic iron and sulfur oxidizers counts ranged from 0 to $6.6 \times 10^{4}$ bacteria/g dry ore (Table 2). Bacterial diversity was low, with mostly sulfur oxidizers comprised of either T. ferrooxidans or T. thiooxidans. Probably due to recent acid-curing, bacterial counts were low on Dump C(1) as compared to Dump C(2). Therefore, to determine whether the bacteria would adapt over time, additional samples were analyzed three months later. These included a sample from the recently acid-cured Dump B(4), and a new sample from Dump C(1). No viable bacteria were recovered from the Dump B(4) sample. The new sample from Dump C(1)-35, taken approximately 3 months after its initial acid-curing, now contained $1.4 \times 10^{6}$ bacteria/g dry ore, although diversity was still low with detection of T. ferrooxidans only (Table 2).

Moderate thermophiles were recovered from one hole on Dump C(1) and from all three samples taken on Dump C(2). Cell counts ranged from $1.0 \times 10^{4}$ to $3.8 \times 10^{5}$ moderate thermophiles/g dry ore (Table 2). All were iron oxidizers with the exception of sample $\mathrm{C}(2)-9$, which contained $4.3 \times 10^{3}$ sulfur oxidizers, and sample C(2)-11 which contained Acidiphilium-like heterotrophs. 
Table 2: Cell count data for ore samples from Dumps $\mathrm{C}$ and $\mathrm{B}$ at 30 and $45^{\circ} \mathrm{C}$. Data presented are the original data divided by $10^{3}$.

\begin{tabular}{|c|c|c|c|c|c|c|c|}
\hline \multirow[b]{2}{*}{ Location $^{\mathrm{a}}$} & \multirow[b]{2}{*}{$\begin{array}{c}\text { Depth } \\
(\mathrm{m})^{\mathrm{b}}\end{array}$} & \multicolumn{6}{|c|}{ Cell Numbers ${ }^{\mathrm{d}}$ (cells/g dry ore) } \\
\hline & & $\begin{array}{c}\text { Total } \\
\text { Mesophilic } \\
\text { Cells }\end{array}$ & $\begin{array}{l}\text { Mesophilic } \\
\text { Sulfur } \\
\text { Oxidizers }^{c}\end{array}$ & $T . f$. & F. a. & T. $t$. & $\begin{array}{c}\text { Total } \\
\text { Thermophilic } \\
\text { Cells }\end{array}$ \\
\hline \multicolumn{8}{|l|}{ Dump C } \\
\hline$\overline{C(2)-9}$ & 0 & 570 & 220 & 130 & 220 & 0 & 10 \\
\hline$C(2)-10$ & 0 & 1100 & 890 & 120 & 89 & 0 & 44 \\
\hline$C(2)-11$ & 0 & 1100 & 630 & 330 & 96 & 0 & 380 \\
\hline$C(1)-1$ & 0 & 0 & 0 & 0 & 0 & 0 & 14 \\
\hline$C(1)-2$ & 0.9 & 0 & 0 & 0 & 0 & 0 & 280 \\
\hline$C(1)-3$ & 2.6 & 0.19 & 0 & 0.097 & 0.097 & 0 & 0 \\
\hline$C(1)-6$ & 0 & 46 & 42 & {$[\mathrm{c}]$} & 4.1 & {$[\mathrm{c}]$} & 0 \\
\hline$C(1)-7$ & 0.8 & 66 & 64 & [c] & 1.9 & [c] & 0 \\
\hline$C(1)-8$ & 1.7 & 8.5 & 6.3 & 0 & 2.2 & 0 & 0 \\
\hline$C(1)-35$ & 0 & 1200 & 0 & 1200 & 0 & 0 & \\
\hline$C(1)-35$ & 0 & 1600 & 0 & 1600 & 0 & 0 & \\
\hline \multicolumn{8}{|l|}{ Dump B } \\
\hline $\mathrm{B}(4)-34$ & 0 & 0 & 0 & 0 & 0 & 0 & \\
\hline $\mathrm{B}(4)-34$ & 0 & 0 & 0 & 0 & 0 & 0 & \\
\hline $\mathrm{B}(1)-12$ & 0 & 1300 & 1300 & [c] & 0 & {$[\mathrm{c}]$} & 0 \\
\hline$B(2)-13$ & 0 & 96 & 96 & [c] & 0 & [c] & 1.1 \\
\hline $\mathrm{B}(3)-14$ & 0 & 0 & 0 & [c] & 0 & [c] & 0 \\
\hline $\mathrm{B}(1)-27$ & 0 & 0 & 0 & [c] & 0 & [c] & 0.097 \\
\hline $\mathrm{B}(2)-28$ & 0 & 0 & 0 & [c] & 0 & {$[\mathrm{c}]$} & 0 \\
\hline$B(3)-29$ & 0 & 420 & 420 & {$[\mathrm{c}]$} & 0 & [c] & 0 \\
\hline
\end{tabular}

a Samples are listed as Dump(Pad)-Sample Number, ie. C(i)-1 through C(i)-n.

b Depth scale is zero at dump surface.

c Sulfur oxidizers may include $T$. ferrooxidans and/or $T$. thiooxidans not already listed under those headings due to difficulty in differentiation.

d T. $f .=$ T. ferrooxidans, L. f. = "L. ferrooxidans", F. a. = "F. acidophilus", T. t. $=T$.

thiooxidans. Samples containing no culturable bacteria were shown as "0" but assumed to contain less than 10 cells/g ore.

Results from Dump B surface samples, which received intermittent application of the waste stream, were varied. Three samples contained no culturable mesophilic iron- and/or sulfur-oxidizing bacteria. The three remaining samples ranged from $9.6 \times 10^{4}$ to $1.3 \times 10^{6}$ cells/g of ore, which were all sulfur-oxidizing T. ferrooxidans or T. thiooxidans. Two 
Table 3: Cell count data for liquid samples at 30 and $45^{\circ} \mathrm{C}$. Data presented are the original data divided by $10^{2}$.

\begin{tabular}{|c|c|c|c|c|c|c|c|}
\hline \multirow[b]{2}{*}{ Sample } & \multicolumn{7}{|c|}{ Cell Numbers $^{\mathrm{a}}$ (cells/mL) } \\
\hline & $\begin{array}{c}\text { Total } \\
\text { Mesophile } \\
\text { s } \\
\end{array}$ & $T . f$. & T. $t$. & L. $f$. & $F . a$. & Hets. & $\begin{array}{c}\text { Total } \\
\text { Moderate } \\
\text { Thermophiles }\end{array}$ \\
\hline Dump B “On” Sol'n & $\begin{array}{c}0 \\
\pm 0\end{array}$ & $\begin{array}{c}0 \\
\pm 0\end{array}$ & $\begin{array}{c}0 \\
\pm 0\end{array}$ & $\begin{array}{c}0 \\
\pm 0\end{array}$ & $\begin{array}{c}0 \\
\pm 0\end{array}$ & $\begin{array}{c}0 \\
\pm 0\end{array}$ & $\begin{array}{c}0 \\
\pm 0\end{array}$ \\
\hline Dump A PLS & $\begin{array}{c}0 \\
\pm 0\end{array}$ & $\begin{array}{c}0 \\
\pm 0\end{array}$ & $\begin{array}{c}0 \\
\pm 0\end{array}$ & $\begin{array}{c}0 \\
\pm 0\end{array}$ & $\begin{array}{c}0 \\
\pm 0\end{array}$ & $\begin{array}{c}0 \\
\pm 0\end{array}$ & $\begin{array}{c}0.050 \\
\pm 0.070\end{array}$ \\
\hline Dump B PLS & $\begin{array}{l}210 \\
\pm 29\end{array}$ & $\begin{array}{r}210 \\
\pm 2.8\end{array}$ & $\begin{array}{c}0 \\
\pm 0\end{array}$ & $\begin{array}{c}0 \\
\pm 0\end{array}$ & $\begin{array}{c}0 \\
\pm 0\end{array}$ & $\begin{array}{c}0.70 \\
\pm 0.85\end{array}$ & $\begin{array}{l}140 \\
\pm 21\end{array}$ \\
\hline Dump C “On” Sol'n & $\begin{array}{c}37 \\
\pm 2.5\end{array}$ & $\begin{array}{c}11 \\
\pm 12\end{array}$ & $\begin{array}{r}4.0 \\
\pm 5.7\end{array}$ & $\begin{array}{c}1.5 \\
\pm 2.1\end{array}$ & $\begin{array}{l}1.4 \\
\pm 2\end{array}$ & $\begin{array}{l}19 \\
\pm 0\end{array}$ & $\begin{array}{c}1.0 \\
\pm 1.4\end{array}$ \\
\hline Dump C PLS & $\begin{array}{c}62 \\
\pm 56\end{array}$ & $\begin{array}{c}12 \\
\pm 10\end{array}$ & $\begin{array}{l}1.6 \\
\pm 2\end{array}$ & $\begin{array}{c}13 \\
\pm 11\end{array}$ & $\begin{array}{c}36 \\
\pm 33\end{array}$ & $\begin{array}{c}0 \\
\pm 0\end{array}$ & $\begin{array}{l}100 \\
\pm 71\end{array}$ \\
\hline $\begin{array}{l}\text { Aggregate PLS } \\
\text { Pond }\end{array}$ & $\begin{array}{c}73 \\
\pm 18\end{array}$ & $\begin{array}{c}12 \\
\pm 12\end{array}$ & $\begin{array}{r}1.0 \\
\pm 1.4\end{array}$ & $\begin{array}{l}9.5 \\
\pm 13\end{array}$ & $\begin{array}{c}41 \\
\pm 31\end{array}$ & $\begin{array}{l}9.5 \\
\pm 13\end{array}$ & $\begin{array}{c}42 \\
\pm 11\end{array}$ \\
\hline Raffinate Pond & $\begin{array}{c}14 \\
\pm 11\end{array}$ & $\begin{array}{c}2.7 \\
\pm 2.1\end{array}$ & $\begin{array}{c}0.45 \\
\pm 0.35\end{array}$ & $\begin{array}{c}2.7 \\
\pm 3.3\end{array}$ & $\begin{array}{c}8.5 \\
\pm 6.4\end{array}$ & $\begin{array}{c}0 \\
\pm 0\end{array}$ & $\begin{array}{c}0 \\
\pm 0\end{array}$ \\
\hline Makeup $\mathrm{H}_{2} \mathrm{O}$ & $\begin{array}{l}530 \\
\pm 36\end{array}$ & $\begin{array}{c}0.55 \\
\pm 0.21\end{array}$ & $\begin{array}{c}0 \\
\pm 0\end{array}$ & $\begin{array}{c}0 \\
\pm 0\end{array}$ & $\begin{array}{c}2.9 \\
\pm 0.92\end{array}$ & $\begin{array}{l}530 \\
\pm 35\end{array}$ & $\begin{array}{c}32 \\
\pm 23\end{array}$ \\
\hline
\end{tabular}

a $T . f .=T$. ferrooxidans, L. $f .=$ "L. ferrooxidans", F. a. $=$ "F. acidophilus", T. $t .=T$. thiooxidans, and Hets. = Acidiphilium-like Heterotrophs. Samples containing no culturable bacteria were shown as "0" but assumed to contain less than 10 cells/g ore.

samples also contained moderate levels of iron-oxidizing thermophiles, ranging from 97 to 1100 cells/g of ore (Table 2 ).

Liquid samples incubated at $30^{\circ} \mathrm{C}$ (Table 3) indicated that PLS Pond A, which is mixed with raffinate and the waste stream and sprayed onto Dump B, contained no viable acidophilic bacteria. The "On" solution collected from Dump B also contained no culturable bacteria. PLS Pond B contained $2.1 \times 10^{4}$ cells $/ \mathrm{mL}$, which were comprised mainly of $T$. ferrooxidans and a small number of Acidiphilium-like heterotrophs. PLS from Dump C contained almost an order of magnitude less cells than PLS Pond B, with only $6.2 \times 10^{3}$ 
cells $/ \mathrm{mL}$ representing all four types of iron and sulfur oxidizers (T. ferrooxidans, $T$. thiooxidans, "L. ferrooxidans" and "F. acidophilus"). The Aggregate PLS Pond contained $7.3 \times 10^{3}$ cells $/ \mathrm{mL}$, again with all four types of iron and sulfur oxidizers represented.

"On" solution from Dump C (1) contained $3.7 \times 10^{3}$ cells $/ \mathrm{mL}$, while the raffinate pond contained $1.4 \times 10^{3}$ cells $/ \mathrm{mL}$ All four types of iron and sulfur oxidizers were represented in both samples. The "On" solution for Dump C(1) also contained Acidiphilium-like heterotrophs. The predominant population in the make-up water (higher $\mathrm{pH}$ ) was acidophilic heterotrophs, probably of the genus Acidiphilium, with only a few $T$. ferrooxidans and " $F$. acidophilus".

"On" solution for Dump B and the raffinate pond samples incubated at $45^{\circ} \mathrm{C}$ (Table 2) contained no culturable moderate thermophiles. PLS Pond A samples incubated at $45^{\circ} \mathrm{C}$ contained only a few iron-oxidizing moderate thermophiles, and the "On" solution from Dump C also contained some iron-oxidizing moderate thermophiles. PLS Ponds B and C both contained approximately $1 \times 10^{4}$ iron-oxidizing moderate thermophiles per $\mathrm{mL}$, which is higher than the 0-100 cells $/ \mathrm{mL}$ present in the "On" solutions. PLS Pond B also contained a few moderately thermophilic heterotrophs as did the Aggregate PLS Pond. The Aggregate PLS Pond contained about one half the iron-oxidizing moderate thermophiles seen in PLS Ponds B and C. In addition, sulfur-oxidizing moderate thermophiles were seen in the Aggregate PLS Pond. The make up water also contained iron-oxidizing and heterotrophic moderate thermophiles.

Toxicity results for the MIC study of the waste stream in PLS are summarized in Figure 2. The waste stream was toxic to the cells, even at 3.3 vol\% in the PLS. By 48 hours of exposure, fewer than $10 \%$ of the initial cells remained at all exposure levels, relative to the

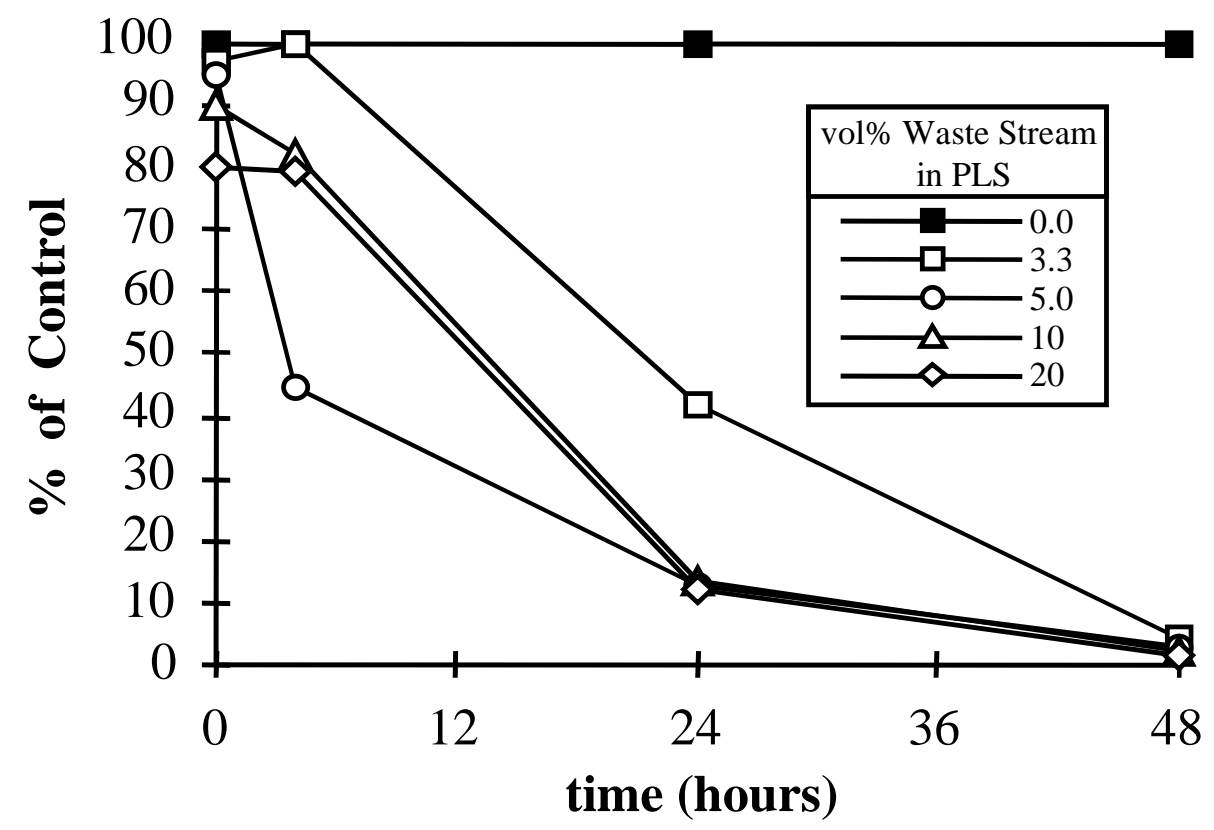

Figure 2: MIC results for waste stream toxicity to cells present in the PLS. Cell counts are presented as percents of the control at each time point, over 48 hours of exposure to the waste stream. 
control. The 20 vol\% waste stream in PLS samples had the highest kill rate, as expected, with cells lagging 50, 90, and $100 \%$ behind the control after 4, 24, and 48 hours, respectively, indicating some toxicity and strong growth inhibition.

\section{DISCUSSION}

While the best leaching solution for oxidized minerals is sulfuric acid, the best for sulfide minerals is acidified ferric sulfate (8). Azurite and malachite are rapidly leached in sulfuric acid solutions, and chrysocolla leaches slightly more slowly. Chalcocite is soluble in acidified ferric sulfate and dissolves in two stages, the first being much more rapid than the second. The ferric sulfate reacts with chalcocite to form sulfuric acid and ferrous sulfate. The ferrous sulfate is then reoxidized by iron-oxidizing bacteria to produce ferric sulfate and the cycle is repeated. Thus, efficient leaching of a mixed oxide/sulfide ore favors diverse mixtures of iron- and sulfur-oxidizing bacteria capable of ferric regeneration, including mesophiles, moderate thermophiles, and heterotrophs.

All cell counts from Dump C(1), which was recently acid-cured, were one or more orders of magnitude lower than from Dump C(2) (leached for about 100 days). After additional samples were obtained to investigate the possibility that acid curing was detrimental to the microbial populations, no viable cells were seen in the sample taken from the newly acid-cured Dump B(4). This indicates that acid curing killed the microbial populations. The sample from Dump C(1) collected three months later had $1.4 \times 10^{6}$ cells $/ \mathrm{g}$ ore, which is comparable to what was seen earlier on Dump C(2). The number of bacteria on Dump C(2) and C(1) after three months of leaching were high enough to support bioleaching and ferric regeneration, but species diversity was low, also a potential result of acid curing. Most bacteria recovered on the overlay plates oxidized only sulfur. When these organisms were subcultured, some were able to oxidize iron, and one colony type's rRNA sequence was investigated and was found to be similar to T. ferrooxidans. This observation may also be an indication of the stress on the microbes from acid curing.

The PLS sample from Dump C contained $10^{4}$ culturable leaching bacteria, with more species diversity than was seen in any of the ore samples. It is clear that ore was in general reinoculated with leaching bacteria from raffinate in the "On" solutions. However, PLS populations were more diverse than raffinate populations, suggesting potential toxicity carryover from the extraction process. Cell numbers were an order of magnitude higher in the PLS (except for PLS A) than in "On" solutions, indicating that sulfide ores were present in the dumps and that the bacteria were actively growing. Typically, when the dumps were operating well the ferric iron leaving the dump was $50 \%$ of the total iron. Thus, the lack of ferric iron in the PLS may indicate low microbial activity near the bottom of the dumps. Another explanation could be that iron oxidation was limited by the availability of oxygen in the lower reaches of the dump. Thus solutions percolating through would have been reduced by the chemical reaction between ferric iron and sulfide minerals, producing ferrous iron.

Moderate thermophiles would be expected in areas where the temperature is above $40^{\circ} \mathrm{C}$, generally at subsurface depths where dump temperatures have increased due to exothermic activity from biotic and abiotic sources. Moderate thermophiles were present in low numbers in about half of the ore samples, although they were absent from the other half. Since the only subsurface samples taken were from an area that had been recently acid-cured and all cell numbers were low in that area, low numbers of moderate thermophiles were expected. Water samples contained moderate thermophiles in comparable numbers to 
mesophilic bacteria in all samples except the raffinate pond. This indicates that, as expected, the moderate thermophiles were present in the dumps at depth since the numbers were higher in PLS compared to raffinate.

About 400 Acidiphilium-like heterotrophs were present in one gram of $\mathrm{C}(2)-9$ ore. $\mathrm{C}(2)-11$ ore contained 96 moderately thermophilic acidophilic heterotrophs per gram. Acidiphilium-like heterotrophs were present only in Dump B PLS, Dump C "On" solution, and the Aggregate PLS Pond. Moderately thermophilic heterotrophs were present in Dump B PLS and in the Aggregate PLS Pond. In addition, the makeup water contained $5.3 \times 10^{4}$ Acidiphilium-like heterotrophs and $1.1 \times 10^{3}$ moderate thermophilic heterotrophs per $\mathrm{mL}$, up to 4 orders of magnitude more non-iron-oxidizing heterotrophic bacteria than seen in the other water samples (0 to 2000 cells $/ \mathrm{mL}$ ). This effect was probably due to the low $\mathrm{pH}$ of most water samples compared to the makeup water. Acidiphilium-like heterotrophs, which are among the least $\mathrm{pH}$-tolerant acidophiles, have an optimum $\mathrm{pH}$ around 3 and most strains cannot tolerate a $\mathrm{pH}$ below 2. Acidiphilium-like heterotrophs are important in metal mobilization due to their use of organic materials that are inhibitory to iron-oxidizing autotrophs such as T. ferrooxidans and "L. ferrooxidans". The lack of Acidiphilium-like heterotrophs could thus decrease leaching efficiency.

The waste stream was highly toxic and/or inhibitory to cells in PLS at all concentrations tested. The cells appeared unhealthy on the plates after exposure to the waste stream, showing limited ability to oxidize iron, while the control cells increased in number by two orders of magnitude. This effect was likely due to the low $\mathrm{pH}$ and to the presence of toxic arsenic and fluoride in high concentrations. Because of this, potential problems were indicated for Dump B. PLS Pond A, which contained a mixture of PLS from Dump A and the waste stream, was mixed intermittently with "On" solution and sprayed onto Dump B. This could explain the variable cell numbers seen on Dump B, since some areas could have received more frequent or concentrated applications of the waste stream. There was also a decrease in the diversity of the organisms present on Dump B, possibly due to differing tolerances to the waste stream. Thus, leaching of mixed oxide/sulfide dumps could be improved by minimizing or eliminating recycle of the waste stream onto dumps containing sulfide ore, and/or by recycling only to dumps containing oxide ore.

This study identified several problems with the microbial ecology at the dump leach operation tested, using the overlay plating technique. The ability to look at cell diversity and numbers was beneficial to this end, since other available techniques may not have presented as clear a picture of the problems with the leaching operation. For example, the use of MPN with ferrous sulfate would not have differentiated between $T$. ferrooxidans and " $L$. ferrooxidans". "Ferromicrobium acidophilus", which requires yeast extract and ferrous iron, would not have been detected. The use of 16S rRNA gene analysis or 16S-23S rRNA gene spacers would have required more labor and time than plating, and would only indicate which species were present; no information on the numbers of each species would have been obtained. In addition, information on the presence of moderate thermophiles may not have been obtained, since these bacteria are more difficult to lyse than mesophilic bacteria. Immunofluorescence probes would only work for organisms to which probes have been developed, and would miss any other species that might be present. Finally, fatty acid methyl esters would not give as much information on species present and their numbers. Thus, the overlay plating method is more versatile as a screening technique for characterizing the microbial ecology of leaching operations. 


\section{CONCLUSIONS}

Efficient copper bioleaching depends on the microbial ecology of the system. The majority of techniques available for studying the microbial ecology of natural systems are good for identifying bacterial species but are generally unsuited for enumeration of the species, or vice versa. The overlay plating technique used here is a useful tool for microbial ecology studies of mining environments, since it overcomes these problems. This technique was used to determine the effect of acid curing and of recycle of a toxic, acidic waste on the microbial ecology of a combined copper oxide/sulfide dump leach operation. Acid curing eliminated culturable bacteria in the dump, although inoculation from the "On" solution reestablished a less diverse microbial community after 3 months or so. In addition, results were used to show that the waste stream was not only highly toxic, but it also decreased the diversity in the surviving population. Decreased diversity in the leaching population can adversely affect copper recovery, and so is an important economic concern.

\section{ACKNOWLEDGEMENTS}

This work was supported by the U.S. Department of Energy under DOE Idaho Operations Office Contract DE-AC07-94ID13223.

\section{REFERENCES}

1. Goebel, B.M. and Stackebrandt, E., 1994. Cultural and Phylogenetic Analysis of Mixed Microbial Populations Found in Natural and Commercial Bioleaching Environments. Applied and Environmental Microbiology, 60(5) 1614-1621.

2. Brierley, J.A. 1997. Microbial Populations in Mineral Biooxidation Processes. In: IBS BIOMINE 97 Conference Proceedings, Australian Mineral Foundation. pp. PSC.1PSC1.10.

3. Schippers, A., Hallmann, R., Wentzien, S., and Sand, W., 1995. Microbial Diversity in Uranium Mine Waste Heaps. Applied and Environmental Microbiology. 61(8) 29302935.

4. Espejo, R. and Romero, J., 1997. Bacterial Community in Copper Sulfide Ores Inoculated and Leached with Solution from a Commercial-Scale Copper Leaching Plant. Applied and Environmental Microbiology 63(4) 1344-1348.

5. Lawson, E., 1997. The Composition of Mixed Populations of Leaching Bacteria Active in Gold and Nickel Recovery from Sulphide Ores. In: IBS BIOMINE '97 Conference Proceedings, Australian Mineral Foundation. pp. QP4.1-QP4.10.

6. Franzmann, P. and Williams, T. 1997. Biomass and Microbial Community Composition in an Arsenopyrite Oxidation Bioreactor Determined by Phospholipid-Derived Fatty Acid Methyl Ester Composition and Content. IBS BIOMINE '97 Conference Proceedings, Australian Mineral Foundation. pp. QP1.1-QP1.10.

7. Johnson, D.B., 1995. Selective Solid Media for Isolating and Enumerating Acidophilic Bacteria. Journal of Microbiological Methods. 23:205-218.

8. Fletcher, J., 1985. Typical Copper Oxide Ore Leaching Operations. In: SME Mineral Processing Handbook, Weiss N. editor. Society of Mining Engineers. New York NY pp. $14 \mathrm{D}-1$ to $14 \mathrm{D}-15$. 